\title{
Reconstructing Late Quaternary fluvial process controls in the upper Aller Valley (North Germany) by means of numerical modeling.
}

\author{
A. Veldkamp ${ }^{1}$, M.W.Van den Berg ${ }^{2}$, J.J.Van Dijke ${ }^{3}$ \& \\ R.M. Van den Berg van Saparoea ${ }^{1}$ \\ * Corresponding Author \\ 1 Laboratory Soil Science and Geology, Dept. Environmental Sciences, Wageningen \\ University, P.O.Box 37, 6700 AA Wageningen, the Netherlands. \\ 2 NITG-TNO Geological Survey of the Netherlands, P.O Box 51 1, 8000 AM Zwolle, \\ the Netherlands \\ ${ }^{3}$ Department of Applied Earth Sciences, Delft Technical University, Mijnbouwstraat 120, \\ 2628 RX, Delft, the Netherlands.
}

Manuscript received: March 2001; accepted: February 2002

\begin{abstract}
The morpho-genetic evolution of the upper Aller valley (Weser basin, North Germany) was reconstructed using geological and geomorphologic data integrated within a numerical process model framework (FLUVER-2). The current relief was shaped by Pre-Elsterian fluvial processes, Elsterian and Saalian ice sheets, followed by Weichselian fluvial processes. Structural analysis based on subsurface data and morphological interpretations were used to reconstruct uplift/subsidence rates. A detailed analysis led to the hypothesis that we are dealing with either a NNW-SSE or a WSW-ENE oriented compression leading to uplift in the upper Aller valley. It is also hypothesised that the NNW-SSE compression might have caused strike-slip deformation leading to differential block movement and tilt. Two different uplift rate scenarios were reconstructed and used as a variable parameter in numerical modelling scenarios simulating the Late Quaternary longitudinal dynamics of the Aller. Each different scenario was run for 150.000 years and calibrated to the actual setting. The resulting model settings were consequently evaluated for their plausibility and validity. Subsequently, regional semi-3D simulations of valley development were made to test the two tectonic stress hypotheses. Differential tectonic uplift and regional tilt seems to have played an important role in shaping the current valley morphology in the upper Aller. Unfortunately, due to the uncertainties involved, we were unable to discriminate between the two postulated tectonic stress scenarios.
\end{abstract}

Keywords: fluvial system, geomorphology, neo-tectonics, process modeling, tectonic stress, terraces, uplift.

\section{Introduction}

Many European valleys have been shaped and deepened during the Quaternary. This is most obvious for large fluvial basins with valleys containing numerous fluvial terraces witnessing the alternating incision and deposition phases. In north-west Europe all large none glaciated fluvial systems draining into the North Sea display such a fluvial record in their middle and lower reaches. Well known examples are found in the Thames, Maas and Rhine valleys (Bridgland, 2000). In the upper reaches fluvial records are usually fragmentary. This is especially true for systems in the relief rich areas associated with Palaeozoic fold belts.
These so-called middle mountainous regions all have in common the fact that they have undergone a renewed uplift since the Late Pliocene to Early Quaternary. Possible explanations for this phenomenon are still under debate (Goes et al., 2000; Westaway, 2001) but there are many theories on the causes for such uplift, such as differences in shallow mantle temperatures, intra-plate stress, flow in the lower continental crust and erosional isostasy. A link between Quaternary climate oscillations and crust movements is provided by the observation that when the climate oscillations increased in magnitude during the Middle Pleistocene the uplift rates as reconstructed from terrace staircases, have also increased significantly (Van 
den Berg \& Van Hoof, 2001). For NW Europe uplift rates since the middle Pleistocene range between $0.04-0.1 \mathrm{~m} / \mathrm{ka}$ (Westaway, 2001; Westaway et al., 2001).

In many smaller fluvial systems and in the upper reaches of the large systems a similar complex interaction of tectonic and climate has taken place, unfortunately hardly any sedimentary record is left to date or correlate. Often the current valley geomorphology is one of the few keys to past conditions. Because fluvial systems transport only a limited amount of water and sediments in their upper reaches it is usually impossible to compensate all effects of uplift and different lithology; this is often referred to as a non-graded system. That is why structural and lithological control over fluvial morphology is quite common in such systems (Bloom, 1998). In Northern Europe we have the complicating interference of large ice sheets during the Quaternary. These ice sheets have caused glacial erosion during advances or sub-glacial erosion during de-glaciation. Many small fluvial systems in North Europe are still adjusting to the morphological changes these ice sheets caused (Eissmann \& Litt, 1995).

Within the scope of a project on the assessment of the stability of a radioactive waste disposal for fluvial erosion, a reconstruction of Late Quaternary valley development at the disposal site was made. This site, ERA Morsleben (ERAM), is situated in the upper Aller (Weser basin, North Germany) system. In this upper reach system we find traces of both glacial and fluvial processes. In general we were faced with a fragmentary fluvial sedimentary record. We therefore had to rely heavily on morpho-genetic reconstructions to generate hypotheses, which were subsequently evaluated by means of numerical modelling with the FLUVER-2 model set (Veldkamp \& Van Dijke, 1998; 2000).

It is the aim of this paper to demonstrate how we derived our main hypotheses and how we evaluated their plausibility by means of numerical modelling.

\section{Study Area}

The Aller valley is situated in the upper reaches of the Weser basin and is situated in the Sub-Hercynian basin, which is situated between the Harz and Flechtinger-Rosslauer upthrown blocks or horsts (Fig. 1).

The Harz horst consists mainly of Palaeozoic sediments and intrusive rocks. The Flechtinger-Rosslauer block is part of a fault ridge zone where sediments with Devonian, Carboniferous and Permian ages are exposed. Within the Sub-Hercynian Basin sediments have been net accumulating from the Permian to the Quaternary. During the Upper Cretaceous the basin has known a period with inversion tectonics causing both local compression and extension structures. During the Permian (Zechstein) large amounts of salt accumulated. Due to pressure differences within the

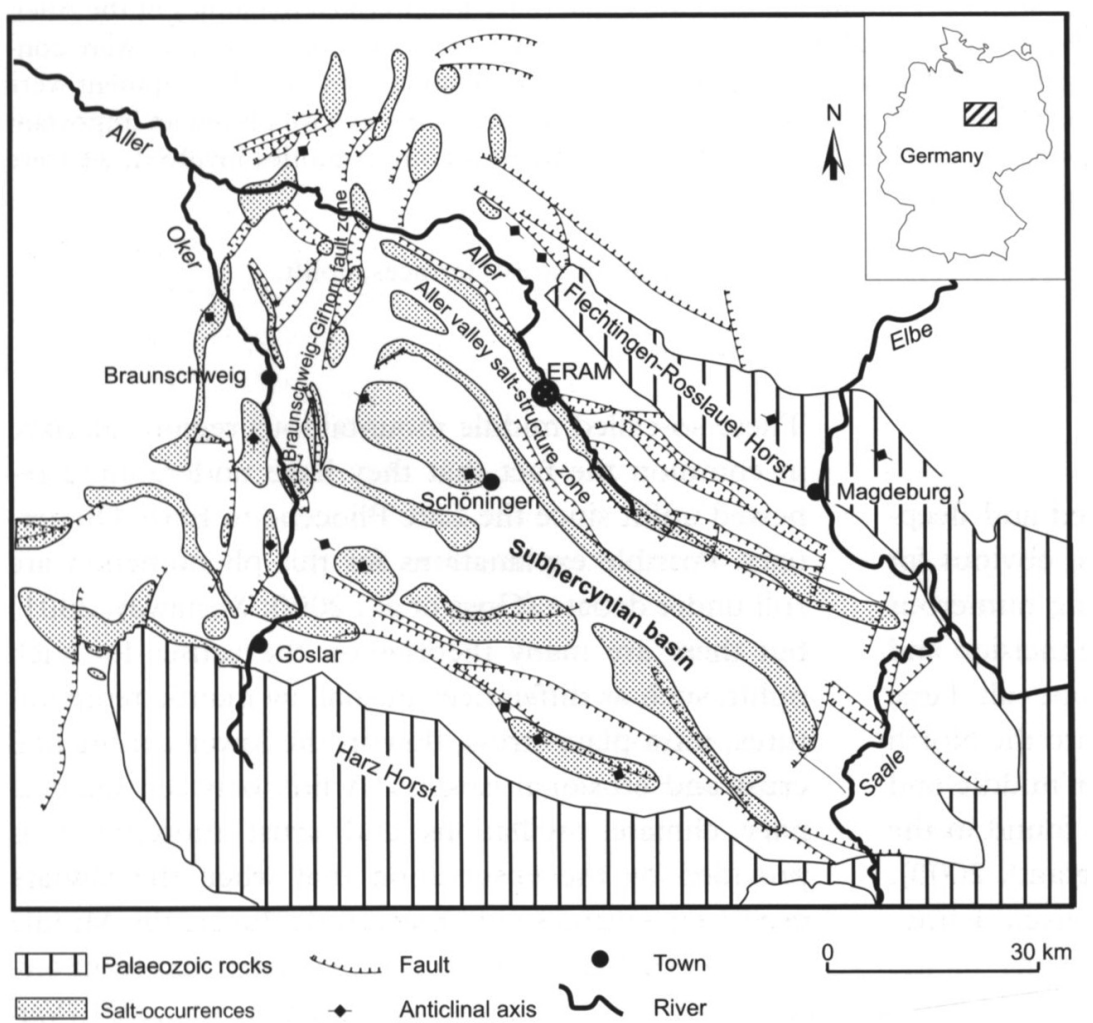

Fig. 1. Structural setting of the upper Aller valley in the Sub-Hercynian basin. ERAM is the site for the assessment of the stability of a radioactive waste disposal for fluvial erosion at Morsleben. Adapted from tectonic Atlas of NWGermany 1:300.000, Bundesanstalt für Geowissenschaften und Rohstoffe. Hannover. 
salt layers, these salt layers reorganised into salt structures (diapirs, domes, pillows and walls), that intruded into the overlying sediments, causing strong local crust deformation due to halokinesis. Within the SubHercynian Basin, graben structures are commonly found to be associated with the salt structures that followed these former extension-zones (Fig. 1). The upper Aller valley, for example, follows the structure of one of these former extension zones, the Aller Graben structure. The main phase of salt intrusion took place during the Late Cretaceous and early Tertiary. Associated with the Aller Graben a large elongated salt structure, the 'Aller valley salt structure zone', is found below and adjacent to the actual Aller valley. Salt movement (halokinesis) causes local uplift and crust deformation in the Sub-Hercynian Basin (BGR, 1996), unfortunately, no specific data from the Aller salt structure are known. Local salt dissolution by groundwater (subrosion) gave rise to local karst depressions, where depending on the timing of the dissolution, either Tertiary or Quaternary sediments could accumulate (Kugler \& Villwock, 1995; Urban et al., 1988). All these tectonic processes have caused a mosaic of separate tectonic blocks in the subsurface of the upper Aller valley area (Best, 1996; BGR, 1996; Voigt, 1997).

During the Quaternary at least two major ice sheets have covered the study area, the Elsterian and Saalian ice sheets (Ehlers et al., 1984). The study area was below the edge of the ice sheets during these main ice advances. The morphology at the basis of the Quaternary deposits reflects the erosive features associated with the first ice-sheet advance during the Elsterian. Pre-Elsterian fluvial deposits, gravels and sands with no trace of Scandinavian provenance, are only rarely found in the current landscape.

The majority of the Quaternary deposits are associated with the Elsterian and Saalian glaciations. The upper Aller valley was below the edge of the maximal ice extend and has undergone only minor alterations compared to the more northern drainage basins (Eissmann et al., 1995). Sub-glacial melt water channels of the Elsterian ice sheet eroded depressions of over $100 \mathrm{~m}$ into the subsurface causing deep local lakes and depressions (Ehlers \& Linke, 1989; Piotrowski, 1994).

Although the Weichselian ice sheet didn't enter the Aller basin, it advanced up to the Elbe river, somewhat less than 100 kilometres away (Ehlers, 1990). This distance makes it quite possible that some forebulge effects (spatial glacio-isostasy response) causing local uplift affected the study area during the Weichselian glaciation (Johnston et al., 1998).

\section{Material and Methods}

We made a morphometric analysis based on existing geological, geomorphological and topographical maps sheets. Longitudinal profiles and cross-sections were made in order to link and combine relevant information to facilitate the morphogenetic interpretation. A set of plausible interpretations was formulated as hypotheses, which were subsequently tested by means of numerical modelling with the FLUVER-2 model set.

\section{Modelling methodology}

The FLUVER-2 modelling set simulates both longitudinal profile and valley development and is based on a robust downscaling approach (Veldkamp \& Van Dijke, 1998). This means that detailed sedimentological aspects such as channel dynamics or sediment grain size are not incorporated within the model description. Thus, the model provides a strong simplification of real-world fluvial behaviour. Nevertheless, numerical modelling of highly simplified stream systems enables us to demonstrate various types of nonlinearity (Veldkamp \& Van Dijke, 2000). Longitudinal profile models, like the one used, should be seen as simplified representations of the real world, useful for guiding further research and to challenge existing formulations, rather than pretending to be an exact, verified copy of the real world (Oreskes et al., 1994).

The longitudinal model describes fluvial dynamics on a long-term and basin-wide scale with equations that relate the sediment transport capacity of the fluvial system to discharge, topography and slope processes (Veldkamp \& Van Dijke, 1998, 2000). Landscape instability and related slope processes are linked to the climate input by assuming that hill slope processes and sediment yield are maximal in highrelief areas during stadial/glacial stages and minimal during interstadial or interglacial stages. These climate-related changes in sediment supply are confirmed by ${ }^{10} \mathrm{Be}$ erosion rate measurements (Schaller et al., 2002). Assuming mass continuity and dynamic equilibrium, the model quantifies the fluvial response to perturbations in the external forcing variables. It calculates a sediment flux resulting from the difference in sediment detachment rate and settlement rate from node to node for $1-\mathrm{km}$ segments along the longitudinal river profile. A positive sediment flux at a given position on the profile raises the height of the inter-nodal profile segment and thus mimics a sedimentation event. A negative sediment flux lowers the height of the inter-nodal profile segment and represents the erosion process. Veldkamp \& Van Dijke 
(2000) provide the mathematical relations, Tebbens et al., (2000) describe an extensive calibration exercise of the longitudinal profile model for the Maas system and Tebbens \& Veldkamp (2001) extensively discuss the model limitations and sensitivities of both the longitudinal profile and local valley formation models. The local valley development is simulated with a fluvial terrace model originally developed to study fluvial terrace genesis on Quaternary time spans. The model has a coarse grid resolution $(100 \star 50 \star 1 \mathrm{~m})$ and has time steps of $1 \mathrm{ka}$. The model has been applied for several NW European systems: Allier (Veldkamp, 1992), Loire (Veldkamp \& Van Dijke, 1998) and the Maas (Veldkamp \& Van den Berg, 1993). The sensitivity of the model is in the order of magnitude of \pm 2 grid units horizontally and one 1 grid unit vertically (Tebbens \& Veldkamp, 2001). For the Aller case study this means $200 \mathrm{~m}$ along the river, $100 \mathrm{~m}$ perpendicular in the river and $1 \mathrm{~m}$ in altitude. The model can be dynamically linked to the longitudinal profile model. The calculated longitudinal erosion and deposition volumes and river/valley gradients are then used as inputs in the valley formation model.

\section{Results and Discussion}

\section{Morphogenetic reconstruction}

By means of detailed topographical maps $(1: 25,000)$ the river gradients were calculated (Table 1) and plotted as a longitudinal profile (Fig. 2). This profile shows that the longitudinal profile can be subdivided into two distinct zones:

The 'Lower Aller Valley' zone is situated in a former ice-marginal valley shaped during the Saalian deglaciation.

The 'Upper Aller Valley' zone is characterised by much steeper gradients. Here the river follows the Aller graben structure (Aller talgraben) and has cut a tributary valley to the major ice-margin melt water channel. The steeper gradients are not only found near the watershed but also at the transition from the Aller Graben to the ice-margin valley. The occurrence of an alluvial fan-morphology at the transition zone near Oebisfelde causes the orientation of the gradient line to affect the calculated gradient considerably. $\mathrm{NE}$

Table 1. Calculated gradients along the upper Aller.

\begin{tabular}{ll}
\hline Reach & Gradient \\
\hline 'Unteres Allertal' Reach: Zone 1 & $0.35 \mathrm{~m} / \mathrm{km}$ \\
'Oberes Allertal' Reach: Zone 2 & $1.48 \mathrm{~m} / \mathrm{km}$
\end{tabular}

Transition from zone 1 to zone 2 between Weferlingen and Oebisfelde:

\begin{tabular}{ll}
\hline (NE traject) & $3.30 \mathrm{~m} / \mathrm{km}$ \\
(NW traject) & $1.35 \mathrm{~m} / \mathrm{km}$
\end{tabular}

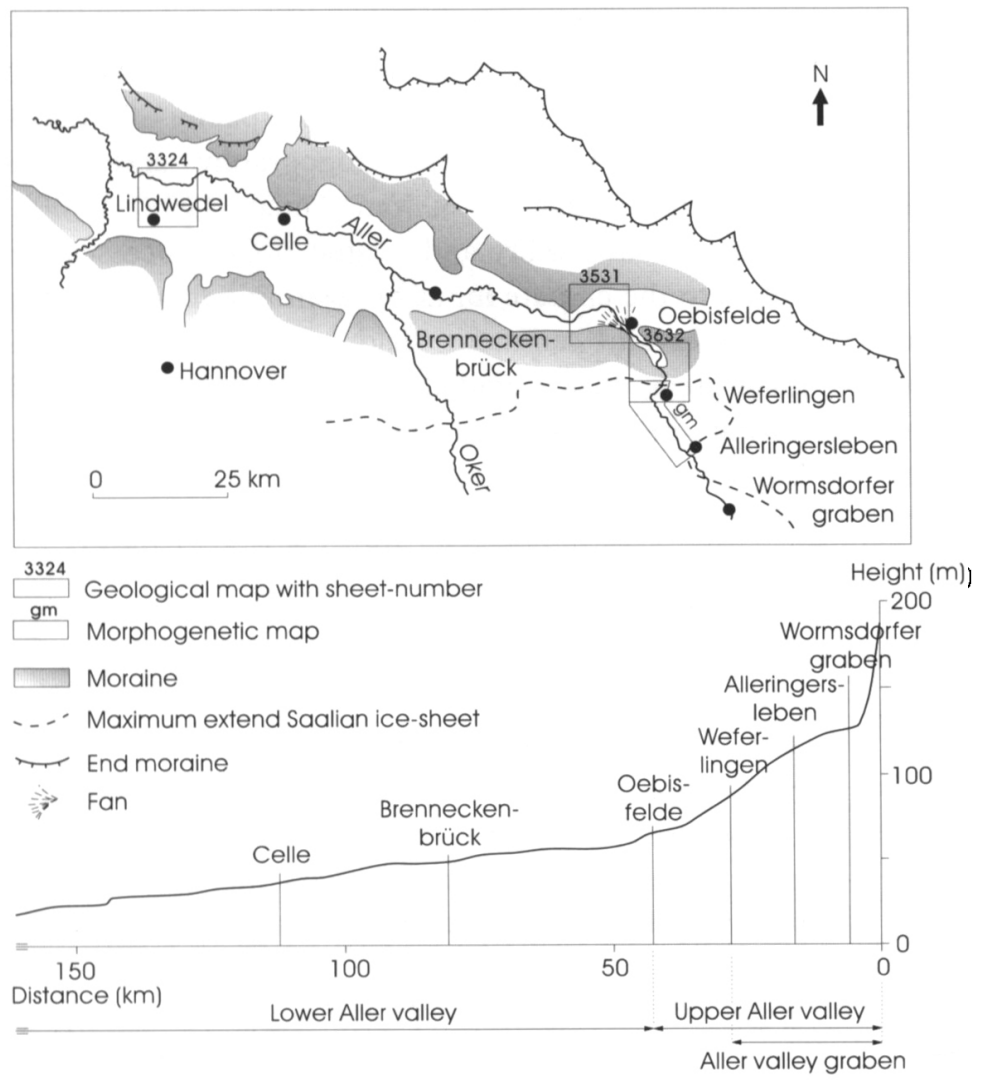

Fig. 2. The morphological setting and longitudinal profile of the Aller system. The used geological and geomorphological map sheets are indicated on the map. The indicated end moraines are of Saalian and Elsterian age. 
oriented gradients are therefore much steeper than the NW oriented gradients (Table 1). The occurrence of a fan indicates that the ice-marginal valley has acted as a local base level for the upper Aller valley. The upper Aller valley itself is a net erosional landform, indicating net uplift since during its formation. There are several possible causes for this net uplift ranging from tectonic regional uplift, glacio-isostasy to halokinesis related uplift.

A systematic inventory of lineaments of the larger Aller region (Fig. 3) reveals two major orientations of the lineaments NNW-SSE and WSW-ENE and indicates that the valley walls of the ice-margin valley (Urstromtal) are rather straight and appear also structurally controlled. This indicates strong structural control of the current landscape morphology.

Two geological maps 1: 25000 are available of the Unteres Allertal reach: map sheet 3324 (Lindwedel) and map sheet 3531 (Oebisfelde). The extent of these maps have been indicated in Fig. 2 (see also appendix 1 for all maps used in study). The geological profiles of these maps demonstrate that the Saalian ice-marginal valley has been partly filled in with Weichselian sediments. The profiles also indicate that a pre Elsterian valley was already in place before the major Elsterian and Saalian ice advances.

The width of the ice-margin valley is highly variable and ranges from $15 \mathrm{~km}$ at Celle to $1.5 \mathrm{~km}$ at Vorsfelde. Had this ice-margin valley been shaped by melt water only, it would not have such an irregular and wide morphology. The $1.5 \mathrm{~km}$ cross-section at

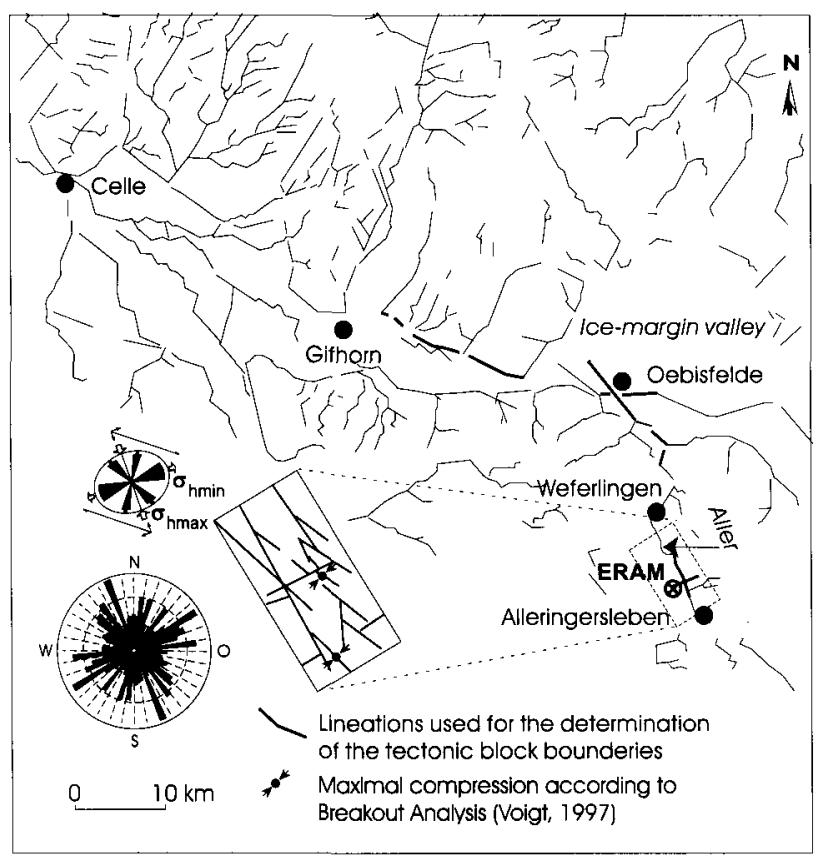

Fig. 3. Regional lineament and fault analysis of the study region. Inset is a structural analyses of the upper Aller region. The break out analysis points are also indicated.
Vorsfelde was apparently sufficiently wide to accommodate the huge discharges of the melting Saalian ice sheet. Thus, the irregular valley width, combined with its straight borders confirms the structural control over its genesis. The first infill occurred during the Saalian deglaciation. This sediment body has an average thickness of $5 \mathrm{~m}$ in map sheet 3531 and thins in a westerly direction to an average of $3 \mathrm{~m}$ in map sheet 3324. The basis of the ice-margin valley has a gradient of only $0.1 \mathrm{~m} / \mathrm{km}$. The upstream part of the Saalian infill comprises channel fills while the more downstream part consists of extensive sediment sheets. The morphology and sedimentology combined suggest a sandur confined within the ice-margin valley, which drained in a westerly direction. This Saalian sandur is now buried below fluvial Weichselian sediments. Eemian sediments or palaeosols at the contact are not reported.

The Weichselian sediment body has a thickness of 12-15 $\mathrm{m}$ near Lindwedel and in the upstream part near Oebisfelde its thickness is highly variable. Here an alluvial fan, which is still visible in the current morphology, is part of this Weichselian sediment body. This fan has a maximum thickness of $15 \mathrm{~m}$ decreasing to $4 \mathrm{~m}$ in westerly direction. Within the Weichselian sediments no further subdivision is possible based on available information. It is apparent that the Aller was the main supplier for the alluvial fan sediments.

For the Upper Aller valley reach one 1:25,000 geological mapsheet Weferlingen (3632) and one geomorphological (gm) mapsheet $(1: 25.000)$ were available (Kugler \& Villwock, 1995) (see also appendix 1 for all maps used in study).

The maps demonstrate that the course of the Aller is partly structurally controlled, as demonstrated by the $90^{\circ}$ turns the valley makes near Weferlingen. Here it clearly follows the major structural directions as indicated in Fig. 3. Furthermore the river follows a graben structure in its upper reaches. The Graben structure is bounded by a step-morphology, which can be either structural or lithological in origin. Some of these steps appear to be small fluvial terrace remnants in-situ, as pre-Elsterian gravels have been found at three such locations above the current valley floor (Fig. 4).

The Elsterian deglaciation in particular left subglacial depressions in the bottom of the Aller valley (locally $>100 \mathrm{~m}$ deep), which were caused by subglacial erosion and were mostly infilled with slope deposits and fine-grained Elsterian and Holsteinian lake deposits. The Saalian ice sheet left mostly tills on the valley floor and walls. During the Weichselian locally approximately 2 to $4 \mathrm{~m}$ of sediments accumulated on 


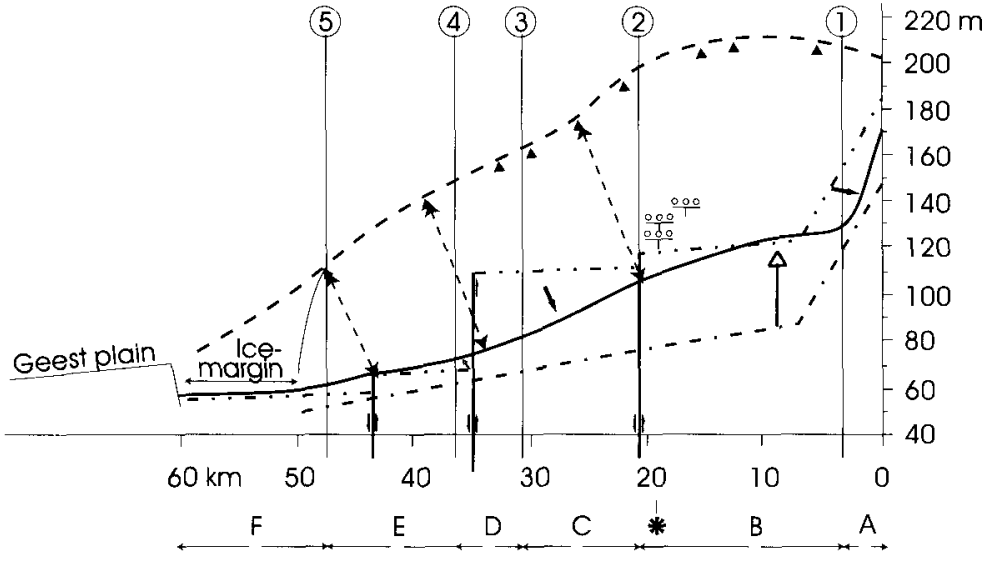

$$
\begin{aligned}
& \text { _. - Watershed ridge } \quad \text { - - Hypothetical profile before uplift } \\
& \leftrightarrow \text { Correlation between } \quad . .- \text { Hypothetical profile after uplift } \\
& \text { watershed ridge and Aller _- Present Aller profile } \\
& \uparrow \text { Tectonic uplift } \quad \text { Profile adaption by fluvial denudation } \\
& \stackrel{0.0}{1} \text { Pre-Elster gravel location * ERAM }
\end{aligned}
$$

the valley floor, mostly associated with subrosion hollows. Most valley sections display erosion features only (Kugler \& Villwock, 1995). The most recent deposit of 1-2 $\mathrm{m}$ of loamy colluvium is related to agriculture generated erosion during historic periods. Kugler \& Villwock (1995) reconstructed an uplift range of $0.03-0.08 \mathrm{~m} / \mathrm{ka}$ based on Weichselian and Holocene deposits. Because this range is too wide we have attempted to refine this estimate by using the pre-Elster gravels.

The erosive morphology clearly suggests a net uplifting setting which is confirmed by the occurrence of eleven terraces in the adjacent Weser valley (Rohde, 1989). We assumed that the three pre-Elsterian gravel occurrences could represent former terraces in situ. By setting the minimum age of pre-Elsterian gravels at either $400 \mathrm{ka} \mathrm{BP}$. (OIS 10) or $440 \mathrm{ka}$ (OIS 12), the onset of the Elsterian glaciation, we can make an average net uplift rate reconstruction. The highest two gravel occurrences are at comparable heights ranging from $27-22 \mathrm{~m}$ above the Aller (Fig. 4). The third occurrence is situated lower on the valley slope at $12-10 \mathrm{~m}$ above the current valley floor. Because slope movements have been active in the area and consequently might have affected the lowest occurrence, we worked out two different hypotheses.

1) The youngest pre-Elsterian deposits are at $27-22 \mathrm{~m}$ above the Aller:

- resulting range of uplift rate $0.0675-0.051 \mathrm{~m} / \mathrm{ka}$ (Average rate $=0.06 \mathrm{~m} / \mathrm{ka}$ )

2) The youngest pre-Elsterian deposits are at $12-10 \mathrm{~m}$ above the Aller:

- resulting range of uplift rate $0.03-0.023 \mathrm{~m} / \mathrm{ka}$ (Average rate $=0.028 \mathrm{~m} / \mathrm{ka}$ )

We will refer to these two hypotheses as the fast and
Fig. 4. Longitudinal profile of the upper Aller valley floor and interpolated watershed ridge. Reconstructed block boundaries and their relative movements are indicated. A-F are the different block elements. The reconstructed initial profile is also indicated. The indicated faults are not proved, they are only postulated. slow uplift scenario respectively. It is interesting to observe that both reconstructed uplift rates fall well within the range of reconstructed regional uplift ranges based on Weichselian and Holocene deposits (Kugler \& Villwock, 1995). They are somewhat lower than those reconstructed for the Palaeozoic Massifs (Westaway, 2001). In this respect it is important to emphasise that we assume that the Aller was a graded system, implying that its incision was able to keep up with uplift. When this is not the case the reconstructed uplift rates are underestimates.

The structural analysis (Fig. 3) revealed several lineaments crossing the Aller valley. A more detailed morphological analysis of the profile morphology (Fig. 4) demonstrated an interesting match between the interpolated watershed morphology and the current longitudinal profile of the Aller (Fig. 4). Both have a convex part near $\mathrm{km} 20$. Possible interpretations for the convex profile are differential uplift rates or different lithologies along the longitudinal profile. Closer examination of the geology of the area indicates no relationship with lithology. Alternatively, it could be argued that the convex shape may be due to the fact that the upper Aller valley is a hanging valley of the ice-margin valley. But the adjustment to such a situation would still result in a concave profile with a nick point. Fluvial processes create concave profiles, only slope processes are able to create convex shapes (Kirkby, 1986). We therefore interpret the observed convex feature in the longitudinal profile as the result of differential uplift along the Aller. The Aller has not been able to keep up with crust dynamics. Whether this lateral variation in uplift rate is gradual or fault bounded remains unsolved. We opted for a fault-bounded approach because of the relationship 
between the valley morphology and the observed lineaments. We therefore simulated the tectonic uplift in the upper Aller valley as differential block uplift (Fig. 4). However, the occurrence of active faulting remains unproven.

We distinguished four major tectonic blocks; the AB block has the highest uplift, followed by the downstream adjacent C-D block and the E block. All blocks in the upper Aller valley have known a net relative uplift. The most downstream block $(F)$, which is the ice-margin valley, has a relative subsidence. This is probably one of the reasons this former ice-margin valley is acting as a regional base level, causing a net sediment accumulation since the Saalian. In Fig. 4., postulated faults and blocks are indicated together with the longitudinal profiles of the watershed and the Aller river.

The general valley morphology was also analysed. A morphological map was made with generalised morphology using a contour interval of $10 \mathrm{~m}$ (Fig. 5).

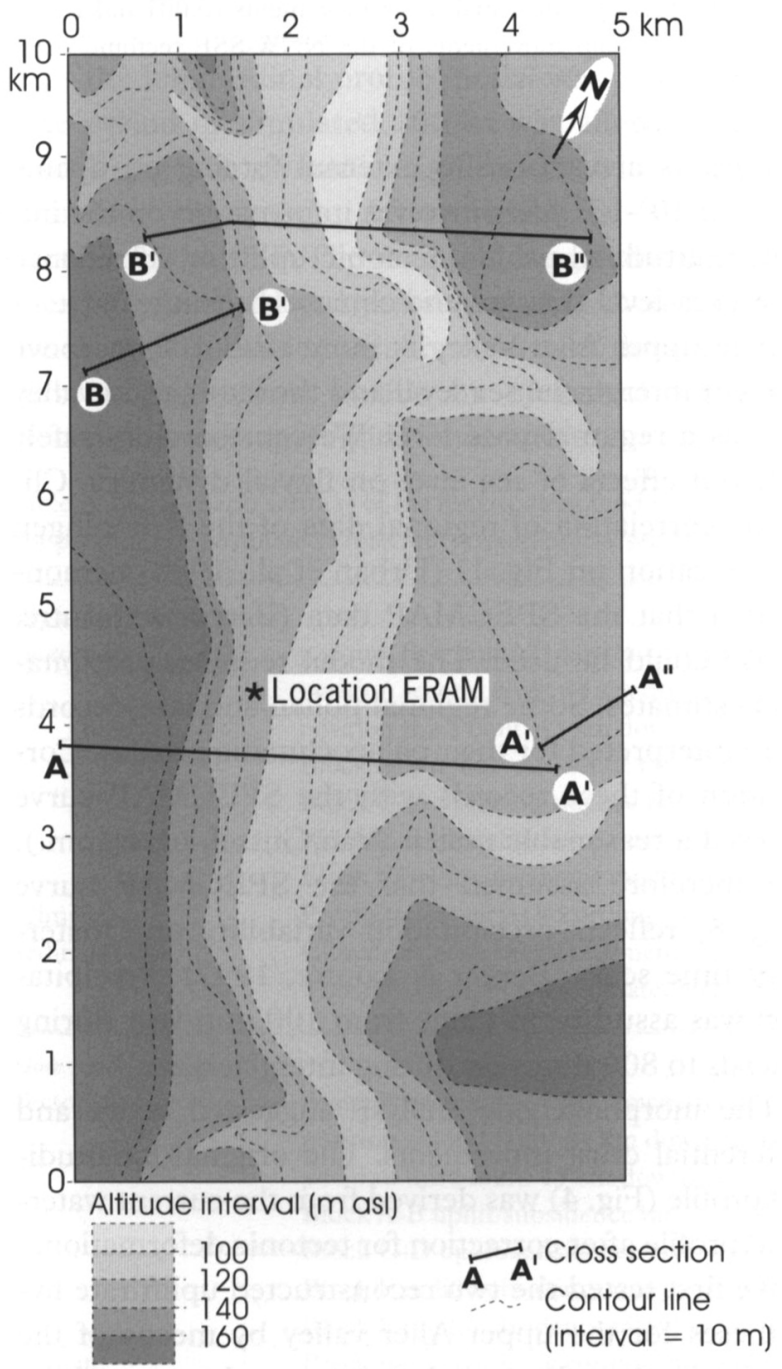

Fig. 5. Schematic map of the general upper Aller valley morphology ( $10 \mathrm{~m}$ interval). The locations of the cross sections of Fig. 6 are indicated.

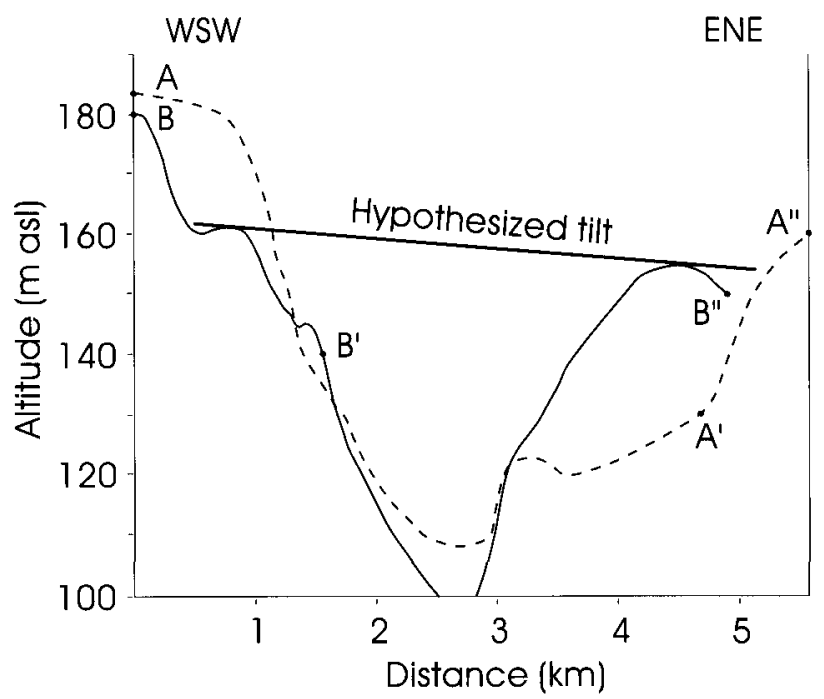

Fig. 6. Two cross sections of the upper Aller valley representing a wide and narrow segment (location see Fig. 5). The relative height of the terrace like features are indicated separately.

More detailed analysis of the upper Aller valley was made by drawing two generalised cross-sections of the valley (Fig. 6). These two cross-sections, a narrow and a wide section, demonstrate certain steps in the valley slopes and display an asymmetric valley (between 120 and $160 \mathrm{~m}$ ). The terraces like features often visible in the field do not show up on the generalised map (Fig. 5) but their approximate heights are indicated in (Fig. 6). The apparent related shoulders and the general valley asymmetry (Fig. 6) suggest that apart from differential uplift along the longitudinal profile a relative tilt of the region took place. This tilt effect decreases downstream (from cross-section A to B) and is indicated in Fig. 6.

Because we now had indications of the type of Quaternary tectonic movements we reanalysed the lineaments of the upper Aller valley (inset of Fig. 3) in more detail. Tectonic deformation caused different uplift of separate tectonic blocks (Best, 1996) and a component of ENE regional tilt is apparent. This could suggest two different tectonic stress directions. The first tectonic stress hypothesis assumes that we have a WSW-ENE oriented stress direction, which causes the general uplift and regional tilt. This hypothesis appears to be confirmed by breakout analyses along two faults in the upper Aller valley (Voigt, 1997) (inset Fig. 3). The second hypothesis postulates a NNW-SSE oriented compression leading to regional uplift and strike-slip deformation. This hypothesis fits well within reconstructed regional patterns of tectonic stress in Europe (Müller et al., 1992). This could have led to reactivation of certain sets of lineaments and caused differential block movements and tilt. The interpretation of the related stress vectors of a hypothesised NNW-SSE stress field is indicated in 
Fig. 3. When we reanalysed the lineaments from the perspective of the second stress hypothesis we could identify nested lineaments which appear related to certain morphological characteristics. We distinguished four wedge-shaped blocks (inset Fig 3). Where these lineaments are converging, a relatively narrow valley occurs and terrace remnants are found, suggesting relatively uplift. These relatively fast uplifting blocks will have more incision (narrower valley), than the relatively slower uplifting blocks. These slower uplift blocks will be more susceptible to lateral erosion causing a wider valley and limiting preservation of terrace remnants. Because we observe both wide valley segments without terrace remnants and narrow segments with terrace remnants we postulate that active strike-slip movements during the Late Quaternary caused relative uplift by converging faults under pressure and subsidence due to local extension (Reading, 1980). Very similar patters were reconstructed for the Roer valley graben system in the Netherlands along the Maas river (Van den Berg, 1994). At first sight the break-out analysis (Voigt, 1997) appears to confirm the first stress hypothesis only, but more detailed analysis shows that the two investigated faults are at converging blocks of the second tectonic stress hypothesis. In this second hypothesis, these converging faults will know an additional uplift related to local stress as measured in the breakout analysis. But the regional setting could still be a NNW-SSE stress field. Unfortunately the break-out analysis is thus not decisive in deciding between the two tectonic stress hypotheses.

The only difference between the two tectonic stress hypotheses in terms of reconstructed crust movements is that the second hypothesis assumes a spatially more complex tectonic movements. In order to elaborate on this second hypothesis we have postulated two nested tectonic blocks in the upper Aller valley: One with a length of approximately $4 \mathrm{~km}$ and a smaller one with a length of $1.6 \mathrm{~km}$ (Fig. 7).

These blocks match with variation from a wider to narrower cross-sections in the Aller valley (Fig. 5). All these structural interpretations lead to a reconstruction of the spatial pattern of relative tectonic movements for the upper Aller valley. The WSW part has the highest uplift and the ENE part the lowest. In Fig. 7 the relative rates are indicated in magnitudes of differential rates $(0.001 \mathrm{~m} / \mathrm{ka})$ on top of the regional uplift rates (approximately 0.06 or $0.03 \mathrm{~m} / \mathrm{ka}$ ) of the two main blocks within the upper Aller valley.

\section{Modelling hypotheses of Aller valley formation}

The model-input data required to simulate fluvial dy-

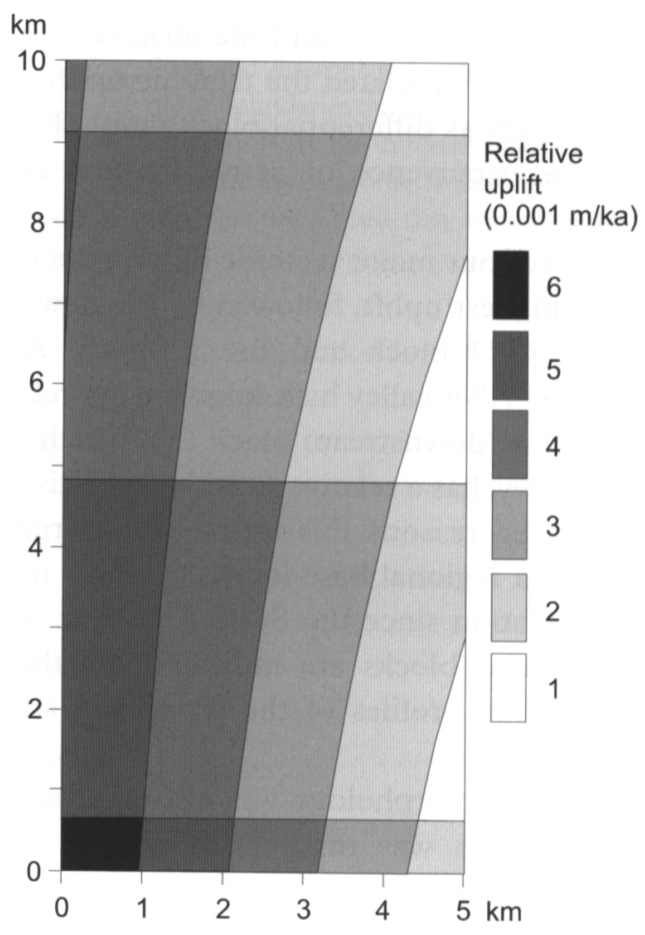

Fig. 7. Postulated differential block movements $(0.001 \mathrm{~m} / \mathrm{ka})$ as a result of strike-slip movements of the NNW-SSE tectonic stress scenario.

namics as a response to external forcing on a time scale of $10^{3}-10^{5}$ years involves information on the initial longitudinal profile, tectonic uplift or subsidence rates, sea-level changes and climate/discharge data.

The upper Aller Valley is more than $100 \mathrm{~m}$ above current interglacial sea level and the ice-margin valley acts as a regional base level. We can therefore safely rule out effects of sea level on fluvial dynamics. Climatic correlation of regional data of the Schöningen site (location on Fig. 1) (Urban et al., 1988) demonstrated that the SPECMAP data (Berger \& Loutre, 1997) could be used. The model requires precipitation estimates. Some regional pollen and lake-records were interpreted for their palaeoclimatic proxies. Correlation of these records with the SPECMAP curve showed a reasonable match (Van Gijssel, pers. com.). We therefore assumed that the SPECMAP curve (Fig. 8) reflects precipitation variability on Quaternary time scale (Berger \& Loutre, 1997). Precipitation was assumed to range from $100 \mathrm{~mm} /$ year during glacials to $800 \mathrm{~mm} /$ year during interglacials.

The morphogenetic analysis suggested active and differential crust movements. The original longitudinal profile (Fig. 4) was derived from the current watershed profile after correction for tectonic deformation.

We first tested the two reconstructed uplift rate hypotheses for the upper Aller valley by means of the longitudinal profile model. Subsequently, we used the valley development model to test the two tectonic stress hypotheses. 


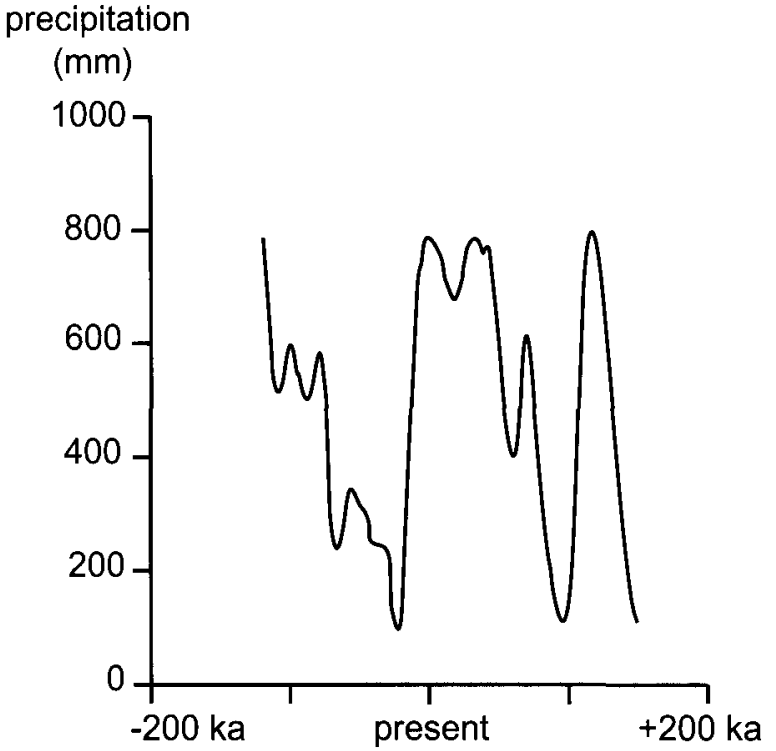

Fig. 8. Precipitation $(\mathrm{mm} / \mathrm{y})$ used as input for the modelling exercise.

\section{Tuning procedure}

First the longitudinal profile model was calibrated. A time period of simulated $100 \mathrm{ka}$ was allowed for the model to reach dynamic equilibrium with its given boundary conditions. After which the simulation starts at $150 \mathrm{ka} \mathrm{BP}$. The resulting longitudinal profile after $150 \mathrm{ka}$ simulated years (present) should match the current condition. Calibration was done for the current longitudinal profile by means of adjusting block uplift rates, precipitation/evaporation ratios, the lateral sediment flux by tributaries in the ice-margin valley and by changing the erosivity values of the bedrock (Table 2).

The semi-3D simulation of the local valley development was done in three subsequent steps during which more tectonic complexity was added.

1. Initially only climate and the main uplift rates were used.

2. The conditions valid for the first (WSW-ENE) tectonic stress conditions were added with differential longitudinal erosion/deposition rates and regional tilt.

3. Finally the spatial differential pattern attributed to tectonic stress hypothesis 2 with the NNW-SSE stress field and strike-slip movements of the upper Aller region (Fig. 7) were added.

Again the simulation started in the past $(150 \mathrm{ka}$ BP) and the model was calibrated for the general valley morphology, depth and width for the first step only. The second and third step were not calibrated, the changes in output were compared relative to the first general calibrated version in order to evaluate a possible improvement of model output. Finally an assessment of the uncertainties involved was made.

\section{Modelling Results}

\section{2-D modelling}

The erosion sedimentation dynamics of the longitudinal profile were simulated for two scenarios, a fast (approx. $0.06 \mathrm{~m} / \mathrm{ka}$ ) and a slow (approx. $0.03 \mathrm{~m} / \mathrm{ka}$ ) uplift scenario. For more details about the model pa-

Table 2. The scenario settings of the longitudinal model simulations. For positions of postulated faults and related blocks see Fig.3.

Rapid uplift scenario

Tectonics: position first fault: $21 \mathrm{~km}$ downstream watershed position second fault: $34 \mathrm{~km}$ downstream watershed position third fault: $43 \mathrm{~km}$ downstream watershed Block A-B uplift $/$ subsidence rate $=+0.07 \mathrm{~m} / \mathrm{ka}$ Block C-D uplift $/$ subsidence rate $=+0.06 \mathrm{~m} / \mathrm{ka}$ Block $\mathrm{E}$ uplift $/ \mathrm{subsidence} \mathrm{rate}=-0.06 \mathrm{~m} / \mathrm{ka}$ Block $\mathrm{F}$ uplift $/$ subsidence rate $=-0.05 \mathrm{~m} / \mathrm{ka}$

Climate Precipitation varies according curve (Fig. 8) between 100 and $800 \mathrm{~mm} / \mathrm{year}$

Sediment flux: $\quad$ Climate related lateral sediment flux (average $0.0001 \mathrm{~m} / \mathrm{ka}$ ) from tributaries downstream fault 3 in ice-margin valley. This flux changes with climate, high rates during glacials and low rates during interglacials.
Slow uplift scenario

Tectonics: position first fault: $21 \mathrm{~km}$ downstream watershed position second fault: $34 \mathrm{~km}$ downstream watershed position third fault: $43 \mathrm{~km}$ downstream watershed Block A-B uplift $/$ subsidence rate $=+0.03 \mathrm{~m} / \mathrm{ka}$ Block C-D uplift $/$ subsidence rate $=+0.02 \mathrm{~m} / \mathrm{ka}$ Block E uplift $/$ subsidence rate $=-0.03 \mathrm{~m} / \mathrm{ka}$ Block $F$ uplift/subsidence rate $=-0.05 \mathrm{~m} / \mathrm{ka}$

Climate Sediment flux:
Precipitation varies according curve (Fig. 8) between 100 and $800 \mathrm{~mm} / \mathrm{year}$

Climate related lateral sediment flux (average $0.0001 \mathrm{~m} / \mathrm{ka}$ ) from tributaries downstream fault 3 in ice-margin valley. This flux changes with climate, high rates during glacials and low rates during interglacials. 


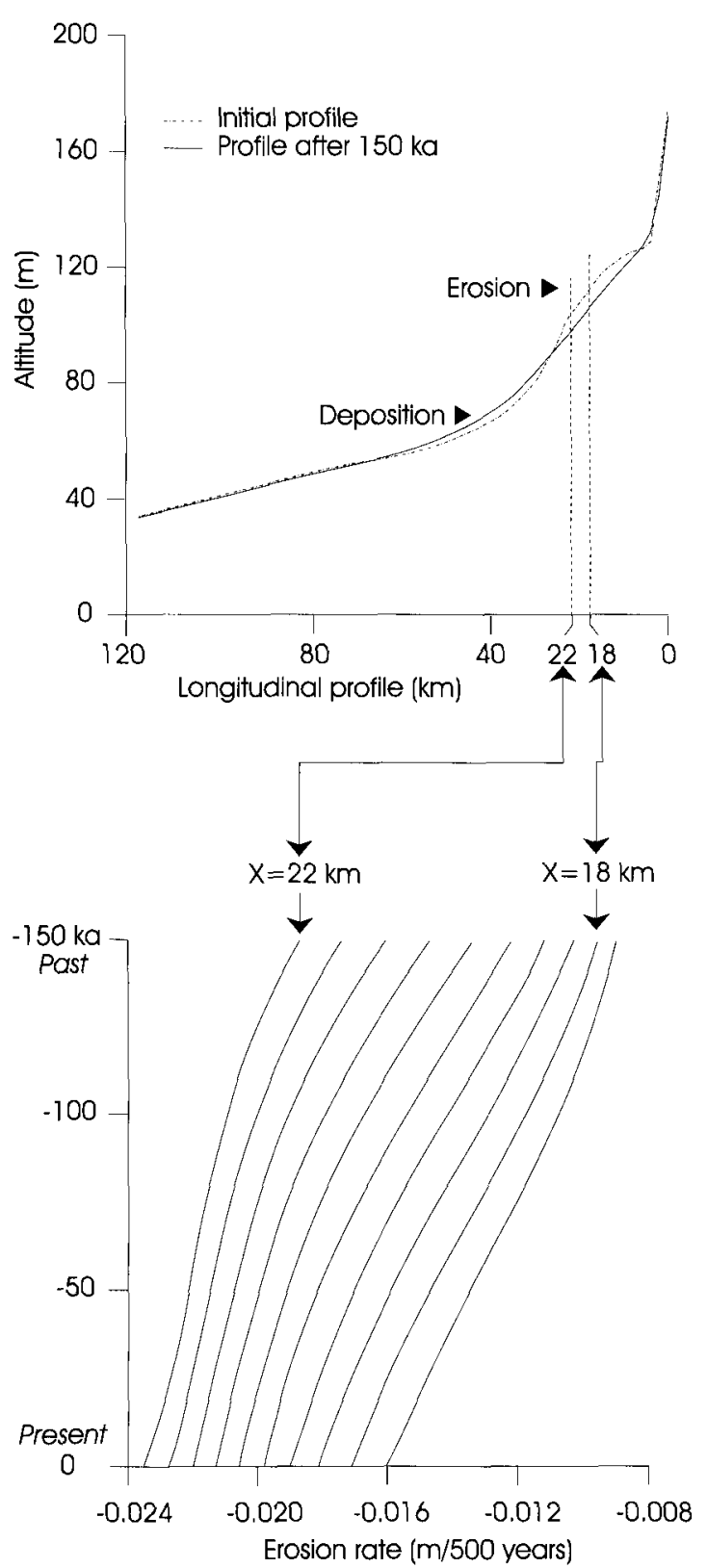

Fig. 9. Simulated erosion and deposition zones along the Aller longitudinal profile. Erosion rates for the last $150 \mathrm{ka}$ are given for the upper Aller valley for the $0.06 \mathrm{~m} / \mathrm{ka}$ uplift scenario. The erosion rate changes for the valley segment between 22 and $18 \mathrm{~km}$ display a strongly filtered climate effect.

rameter settings see Table 2 . Each scenario had some different uplift rates and a different initial profile. More detailed dynamics were recorded for the upper reach ( $\mathrm{x}=18$ to $22 \mathrm{~km}$ ) (Fig. 9).

There were no significant differences in the longitudinal profile development for both scenarios. The only difference is the rate of net fluvial erosion. Note however, that in the case of both scenarios the simulated Aller system is unable to keep up with reconstructed uplift and shapes a characteristic convex profile. This confirms the strong structural control in the upper Aller reach. Although one can observe some climate-related changes in erosion rates during both scenarios, climate plays no significant role in shaping the longitudinal profile. The simulations hereby confirm the strong tectonic control over the fluvial impact in the upper Aller. These model runs in combination appear to confirm the differential uplift hypotheses. Because no clear morphological distinction could be made between the two uplift rate scenarios we cannot falsify one of the two uplift scenarios. Both uplift hypotheses remain valid options.

\section{Semi-3-D modelling}

Because both uplift scenarios remain we evaluated local valley development with the fast uplift rates because this would yield sufficient morphological expression for further evaluation. The valley development model simulation was done with the two tectonic stress scenarios (Fig. 10).

Tectonic stress scenario 1 included differential uplift rates of the four blocks, and the WSW-ENE regional tilt (Fig. $10 \mathrm{~A}$ ). The valley width displays changes along the longitudinal profile and has become asymmetric. Tectonic stress hypothesis 2 includes the same inputs as the first scenarios but now the postulated spatially differential tectonic inputs of Fig. 7 are added (Fig. $10 \mathrm{~B}$ ). Now an even more realistic asymmetric valley emerges. The enhanced asymmetry and the altitude difference between the left and right bank valley shoulder appear more realistic than the previous simulation. In order to make a better comparison of the simplified valley morphology (Fig. 5) with the simulated valley morphology (Fig. 10) two cross-sections of the actual and modelled upper Aller valley are compared for the second tectonic stress scenario (Fig. 11). At first glance they match reasonably well. The model displays a lot of discrete terrace steps, but this is due to the use of discrete grids in the model.

These terrace-like features are not real terraces in the sense that they contain fluvial sediments, they are erosion features only. In particular the asymmetry and the switch from narrow to wider valley segments appear to be well captured by the semi-3-D modelling. Of course we wanted to use the simulations to test our spatially explicit tectonic stress hypotheses. Before we can discuss this in more detail we have to take a look at the uncertainties involved.

Fig. 12 gives an estimate of the uncertainties involved for the two simulated cross-sections in Fig. 11. These uncertainties are derived from the differences between the simulated and actual valley crosssections for $2 \mathrm{~km}$. Only when the differences between the two tectonic stress scenarios are larger than their differences with the real world valley, are we able to discriminate which scenario is more plausible. From 

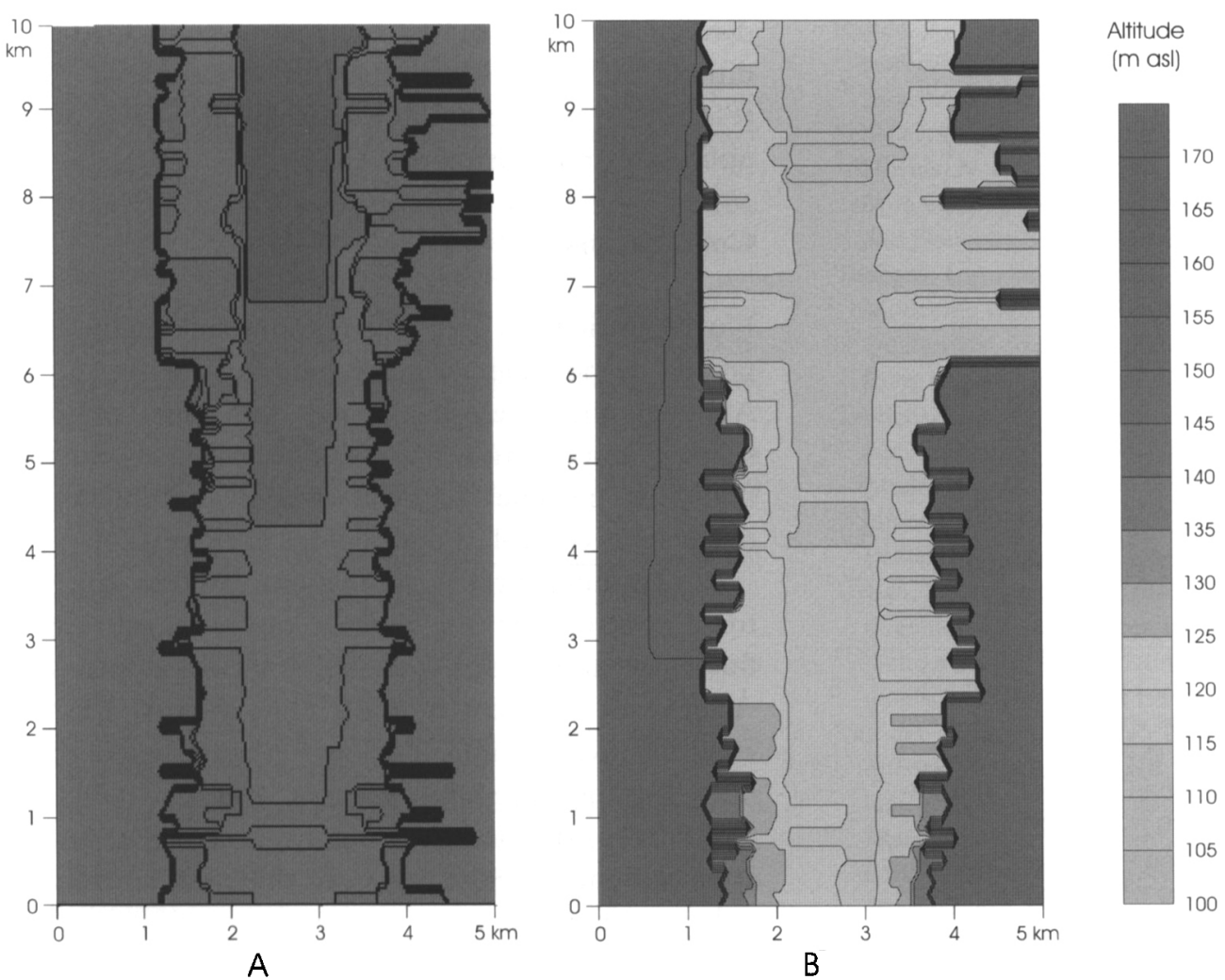

Fig. 10. The output maps of the semi-3-D simulations of valley development for the two different tectonic stress scenarios: A: NNW-SSE stress orientation and $\mathrm{B}$ : WSW-ENE stress orientation.

Fig. 12 it becomes apparent that this uncertainty is far too large to allow any realistic discrimination between the two tectonic stress scenarios (Fig. $10 \mathrm{~A}$ and B). We conclude that the combined effects of differential uplift of the 4 blocks combined with regional tilt appear to be the main tectonic components, which controlled the fluvial dynamics in the upper Aller during the Late Quaternary. A spatial pattern of differential block tectonics, which might be attributed to strike-slip movements, appears likely but remains unproven. This means that both WSW-ENE and NNWSSE oriented stress fields are possible interpretations of the reconstructed crust movements and their simulated impacts on fluvial morphology.
The reconstructed uplift rates for the upper Aller valley are somewhat lower than those reconstructed for the Rhenish Massif, the South of the UK, the Paris Basin and the Massif Central in France (Westaway, 2001; Bridgland, 2000; Maddy et al., 2000; Van den Berg \& Van Hoof, 2001; Veldkamp \& Van Dijke, 1998). This might suggest that we are dealing with differential West European uplift. Van den Berg \& Van Hoof (2001) suggest higher and earlier uplift rates at the Ardenne Rhenish shield than surrounding areas. Our results might confirm this phenomenon and might fit well within the theory of flow in the lower continental crust as a mechanism for uplift (Westaway, 2001). We have found no clear evidence of the

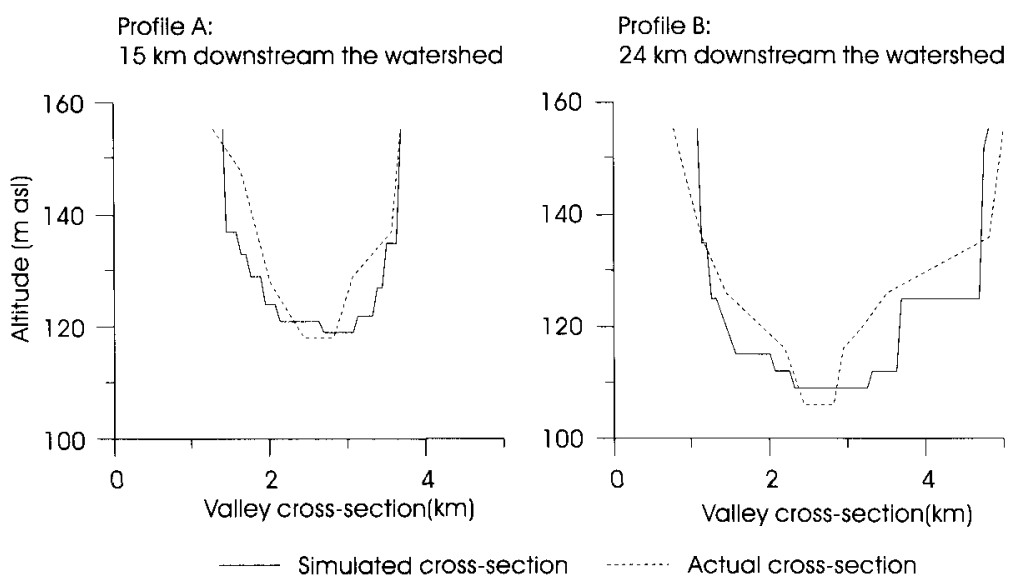

Fig. 11. Match of actual and simulated valley morphology for both the wide and narrow cross-sections in the upper Aller valley for the NNW-SSE tectonic stress field. 


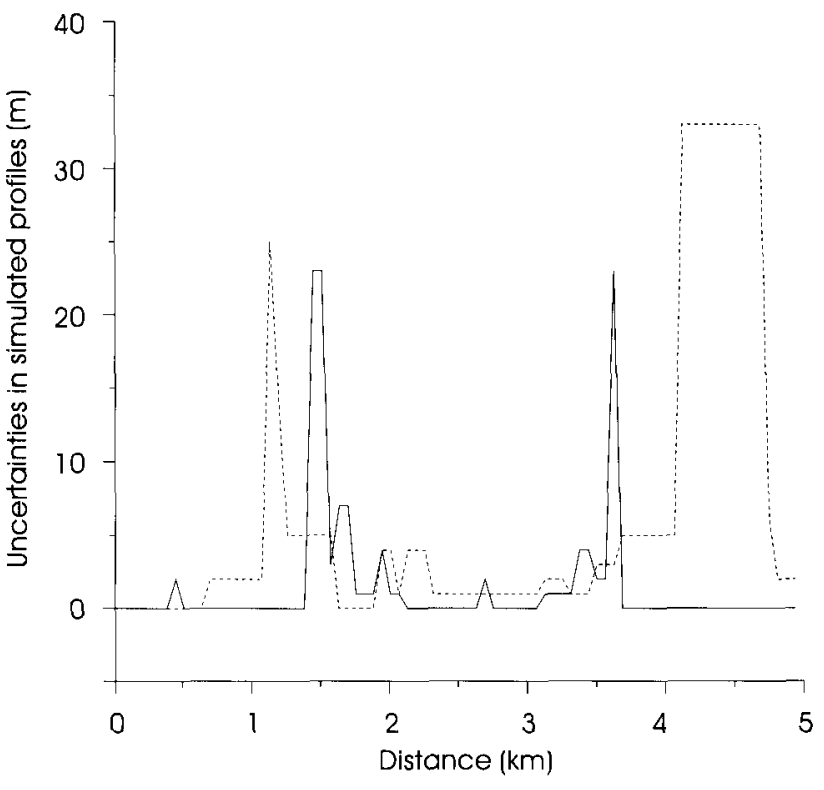

Segment between 14,5 and $15,5 \mathrm{~km}$ downstream the watershed

Segment between 23,5 and $24,5 \mathrm{~km}$ downstream the watershed

Fig. 12. Estimated uncertainties of model output of valley crosssections ( $m$ altitude differences). Uncertainties are based on differences between actual and simulated cross-sections for $1 \mathrm{~km}$ zone.

effects of glacio-isostasy, which may be due to the fact that they are net neutral on the time span (past 150 ka) considered, or due to the poor resolution of our field data.

In upper reach areas the role of sea level is nonexistent and climate effects are limited because the fluvial system is transporting only limited amounts of water and sediments. A tectonic and/or lithological control is therefore most likely to occur and is also commonly observed (Bloom, 1998). A problem with reconstructing uplift rates from incision rates is related to the fact that the fluvial system is usually 'transport limited' and not able to keep up with crustal uplift. The absolute uplift estimates must therefore be considered as minimum estimates only. The upper Aller, for example, is clearly unable to compensate all the differential uplift rates along its longitudinal profile, resulting in a convex shape. On the other hand, specific tectonic effects like regional tilt are clearly traceable in the morphological expression of the valley shape. It appears that specific tectonic stress scenarios can be evaluated qualitatively by means of the observed and modeled morphological expressions.

The fact that the Aller valley contains some terrace like features with some gravel in situ implies that this system has not been incising continuously, indicating graded conditions for part of the time. It could well be that the pre-Elsterian Aller was graded, and since the major ice sheets advanced into the area this dynamic equilibrium has changed to non-graded conditions due to glacio-isostasy. It is clear that more research is needed to solve the distinction between uplift rate and incision rate.

\section{Conclusions}

Fluvial erosion has been a continuous and omnipresent process in the upper Aller valley during the last $150 \mathrm{ka}$. Although fluvial erosion is the dominant landscape shaping process and climate has known many fluctuations, the regional tectonic setting and differential movements control its morphological expression.

Longitudinal profile simulations confirm the tectonic control over the morphological expression of fluvial dynamics. Uplift scenarios for the upper Aller valley with differential uplift rates yielded the observed convex profile. The two reconstructed uplift rates for the approximately last $400 \mathrm{ka}(0.06$ and $0.028 \mathrm{~m} / \mathrm{ka}$ ) did not yield significant different results after calibration. Both rates are therefore considered to be possible estimates.

Semi-3-D valley development simulations demonstrate that the combined effects of differential uplift combined with regional tilt are the main tectonic components that controlled the fluvial valley morphology of the upper Aller region. Reliable discrimination between two postulated tectonic stress scenarios could not be made due to the large uncertainties involved. But a NNW-SSE stress field with related strike-slip movements seems to be the most likely scenario because the qualitative better fit of the semi3-D valley development simulation with reality. The uplift estimates are almost certainly under-estimations because the upper Aller has been unable to compensate all crustal uplift.

\section{Ackowledgements}

Dr A.F.B. Wildenborg (NITG-TNO) and Dr J. Gerardi (BGR) are both thanked for their co-operation and support within the ERA Morsleben project. The thoughtful and constructive review of Thore Szeder and Rob Westaway are highly appreciated. This paper contributes to the International Geological Correlation Program (IGCP) 449.

\section{References}

Berger, A.L. \& Loutre, M.F., 1997. Paleoclimate sensitivity to $\mathrm{CO}_{2}$ and insolation. Ambio 26: 32-37.

Best, G., 1996. Flosstektoniek in Norddeutschland, Erste Ergebnisse der reflexionsseismischen Untersuchungen an der Salzstruktur: Obereres Allertal Zeitschrift der Deutschen Geologischen Gesellschaft 147: 455-464. 
BGR, 1996. Tectonic Atlas of NW-Germany 1:300.000. Bundesanstalt für Geowissenschaften und Rohstoffe, Hannover.

Bloom, A.L., 1998. Geomorphology. A systematic analysis of Late Cenozoic Landforms, Third edition. Prentice Hall (New Jersey USA): $482 \mathrm{pp}$

Bridgland, D.T., 2000. River terrace systems in north-west Europe: an archive of environmental change, uplift and early human occupation. Quaternary Science Reviews 19: 1293-1303.

Ehlers, J., 1990. Untersuchungen zur Morphodynamik des Vereisungen Norddeutschlands unter Berücksichtigung benachbarter Gebiete. Bremer Beiträge zur Geographie und Raumplannung 19: $166 \mathrm{pp}$.

Ehlers, J., Meyer, K.D. \& Stephan, H.J., 1984. The pre-Weichselian glaciations of North-West Europe. Quaternary Science Reviews 3: $1-40$.

Ehlers, J. \& G. Linke, 1989. The origin of deep buried channels of Elsterian age in Northwest Germany Journal of Quaternary Science 4: 255-265.

Eissmann, L., Litt, Th. \& Wansa St., 1995. Elsterian and Saalian deposits in their type area in central Germany. In: Ehlers, J., Kozarski, S. \& Gibbard, P.L. (eds). Quaternary deposits in North-East Europe. Balkema (Rotterdam) 439-464.

Eissmann, L. \& Litt, Th., 1995. Late Pleistocene deposits in central Germany. In: Ehlers, J., Kozarski, S. \& Gibbard, P.L., (eds). Quaternary deposits in North-East Europe: 465-472. Balkema, (Rotterdam)

Goes, S., Loohuis, J.J.P., Wortel, M.J.R. \& Govers, R., 2000. The effect of plate stresses and shallow mantle temperatures on tectonic of north-western Europe. Global and Planetary Change 27: 23-38.

Johnston, O., Wu, P. \& Lambeck, K., 1998. Dependence of horizontal stress magnitude on load dimensions in glacial rebound models. Geophysical Journal International 132: 41-60.

Kirkby, M.J., 1986. A two-dimensional simulation model for slope and stream evolution. In: Abrahams, A.D. (ed.): Hillslope processes. Allen \& Unwin, Inc. (Winchester, Mass., USA): 203222.

Kugler, H.G. \& Villwock, G., 1995. Morphogenetische Kartierung Untersuchungsgebiet ERA Morsleben. Bericht Bundesamt für Strahlenschutz. 11 Anlagen und 5 Tabellen.

Maddy, D., Bridgland, D.R. \& Green, C.P., 2000. Crustal uplift in southern England: evidence from the river terrace records. Geomorphology 33: 167-182.

Müller, B., Zoback, M.L., Fuchs, K., Mastin, L., Gregersen, S., Pavoni, N., Stephanson, O. \& Ljunggren, C., 1992. Regional patterns of tectonic stress in Europe. Journal of Geophysical Research: 11783-11803.

Oreskes, N., Shrader-Frechette, K. \& Belitz, K., 1994. Verification, validation and confirmation of numerical models in the Earth Sciences. Science 263: 641-644.

Piotrowski, J.A., 1994. Tunnel-valley formation in northwest Germany: geology, mechanisms of formation and subglacial bed conditions for the Bornhoeved tunnel valley. Sedimentary Geology 89: 107-141.

Reading, H.G., 1980. Characteristics and recognition of strike-slip fault systems. Spec. Publ. Int. Ass. Sediment. 4: 7-26.
Rohde, P., 1989. Elf Pleistocene Sand-Kies-terrasse der Weser: Erlauterung eines Gliederungsschema für das obere Weser-Tal. Eiszeitalter und Gegenwart 39: 42-56.

Schaller, M., Von Blanckenburg, F., Veldkamp, A., Tebbens, L.A., Hovius, N. \& Kubik, P.W., 2002. A 30 ky record of erosion rates from cosmogenic ${ }^{10} \mathrm{Be}$ in Middle European river terraces. Earth and Planetary Science Letters 204: 307-320.

Tebbens, L.A., Veldkamp, A., Van Dijke, J.J. \& Schoorl, J.M, 2000. Modelling longitudinal profile development in response to Late Quaternary tectonic uplift, sea-level and climate changes: the River Meuse. Global and Planetary Change 27: 165-186.

Tebbens, L.A. \& Veldkamp, A., 2001. Exploring the possibilities and limitations of modelling Quaternary fluvial dynamics. In: Maddy, D., Macklin, M. \& Woodward, J. (eds.): River Basin Sediment Systems: Archives of Environmental Change. Chapter 17, Balkema (Rotterdam): 469-484.

Urban, B., Thieme, H. \& Elsner, H., 1988. Biostratigraphie, quartärgeologische und urgeschichtliche Befunde aus dem Tagebau 'Schoeningen', Ldkr. Helmstedt. Zeitschrift der Deutschen Geologischen Gesellschaft 139: 123-154.

Van den Berg, M.W. \& Van Hoof, T., 2001. The Maas terrace sequence at Maastricht, SE Netherlands: evidence for $200 \mathrm{~m}$ of late Neogene and Quaternary surface uplift. In: Maddy, D., Macklin, M. \& Woodward, J. (eds.): River Basin Sediment Systems: Archives of Environmental Change. Chapter 3, Balkema (Rotterdam): 45-86.

Van den Berg, M.W., 1994. Neotectonics of the Roer Valley rift system. Style and rate of crustal deformation inferred from syn-tectonic sedimentation. Geologie en Mijnbouw 73: 143-156.

Veldkamp, A., 1992. A 3-D model of fluvial terrace development in the Allier basin (Limagne. France). Earth Surface Processes and Landforms 17: 487-500.

Veldkamp, A. \& Van den Berg, M.W., 1993. Three-dimensional modelling of Quaternary fluvial dynamics in a climo-tectonic dependent system. A case study of the Maas record (Maastricht, The Netherlands). Global and Planetary Change 8: 203-218.

Veldkamp, A. \& Van Dijke, J. J., 1998. Modelling long-term erosion and sedimentation processes in fluvial systems: A case study for the Allier/Loire system. In: Benito, G., Baker, V.R. \& Gregory, K.J. (eds): Palaeohydrology and environmental change. Wiley (Chichester): 53-66.

Veldkamp, A. \& Van Dijke, J.J., 2000. Simulating internal and external controls on fluvial terrace stratigraphy: a qualitative comparison with the Maas record. Geomorphology 33: 225-236.

Voigt, E., 1997. Western Atlas: Zusammenfassender Abschlußbericht der Struktur- und Kluftauswertung der CBIL imagedaten des Projektes Morsleben. PESG-248.

Westaway, R., 2001. Flow in the lower continental crust as a mechanism for the Quaternary uplift of the Rhenish Massif, northwest Europe. In: Maddy, D., Macklin, M. \& Woodward, J. (eds.): River Basin Sediment Systems: Archives of Environmental Change. Balkema (Rotterdam): 71-151.

Westaway, R., Maddy, D. \& Bridgland, D., 2001. Flow in the lower continental crust as a mechanism for the Quaternary uplift of southeast England: constraints from the Thames record. Quaternary Science Reviews 79:23-36. 


\section{Appendix I}

\section{Maps used}

BGR 1994. Das Schollenmuster im Sockel NW-Deutschlands, Baldschuhn, R.\& F Kockel, Archv 111089, Blatt $4,1: 500.000$

BGR 1995. Quartärgeologsiche Übersichtskarte 1:500.000 Bundesanstalt für Geowissenschaften und Rohstoffe. Hannover.

BGR, 1996. Tectonic Atlas of NW-Germany 1:300.000, Bundesanstalt für Geowissenschaften und Rohstoffe. Hannover.

Hydrogeologsiche Karte der DDR 1:50.000 nr 904-1/2

Hydrogeologsiche Karte der DDR 1:50.000 nr 904-3/4

Hydrogeologsiche Karte der DDR 1:50.000 nr 1004-1/2

Hydrogeologsiche Karte der DDR 1:50.000 nr 1004-3/4

Geologisches Landesamt Sachsen-Anhalt Lithofazieskarten Quartär 1:50.000 Blatt Nr. 2163 Haldensleben.

Geologisches Landesamt Sachsen-Anhalt 1992.Geologische Karte Sachsen Anhalt - Karte der quartären Bildungen 1:200.000 Blatt 42 Magdeburg.

NLfB 1981 Erläuterungen zu Blatt Nr. 3324 Lindwedel, 1:25.000 Hannover 127 S., 8 Kt.

NLfB 1996. Geologische Karte von Niedersachsen. Blatt Nr. 3531 Oebisfelde 1:25.000, Hannover.

NLfB \& BGR 1974. Geologsiche Übersichtskarte, 1:200.000 Blatt CC3926 Braunschweig. 